\title{
IMMANUEL KANT ON INTELLECTUAL PROPERTY
}

Riccardo $\mathrm{POZZO}^{1}$

- ABSTRACT: This text initially discusses the notion of intellectual property in Kant's philosophy and in the eighteenth century. Next, it restates the problem within a contemporary setting, taking into account the new technologies on reproduction of information.

- KEYWORDS: Kant; intellectual property; piracy; copyright; copyleft.

\section{I}

Corpus mysticum, opus mysticum, propriété incorporelle, proprietà letteraria, geistiges Eigentum. All these terms mean intellectual property, the existence of which is intuitively clear because of the unbreakable bond that ties the work to its creator. The book belongs to whomever has written it, the picture to whomever has painted it, the sculpture to whomever has sculpted it; and this independently from the number of exemplars of the book or of the work of art in their passages from owner to owner. The initial bond cannot change and it ensures the author authority on the work. Kant writes in section 31/II of the Metaphysics of Morals: "Why does unauthorized publishing, which strikes one even at first glance as unjust, still have an appearance of being rightful? Because on the one hand a book is a corporeal artifact (opus mechanicum) that can be reproduced (by someone in legitimate possession of a copy of it), so that there is a right to a thing with regard to it. On the other hand a book is also a mere discourse of the pub-

1 Lecturer (Full Professor) of History of Philosophy at University of Verona. Article received on oct/ 06 and approuved for publication on dec/06. 
lisher to the public, which the publisher may not repeat publicly without having a mandate from the author to do so (praestatio operae), and this is a right against a person. The error consists in mistaking one of these rights for the other" (Kant, 1902, t.6, p.290). The corpus mysticum, the work considered as an immaterial good, remains property of the author on behalf of the original right of its creation. The corpus mechanicum consists of the exemplars of the book or of the work of art. It becomes the property of whoever has bought the material object in which the work has been reproduced or expressed. Seneca points out in De beneficiis (VII, 6) the difference between owning a thing and owning its use. He tells us that the bookseller Dorus had the habit of calling Cicero's books his own, while there are people who claim books their own because they have written them and other people that do the same because they have bought them. Seneca concludes that the books can be correctly said to belong to both, for it is true they belong to both, but in a different way.

The peculiarity of intellectual property consists thus first in being indeed a property, but property of an action; and second in being indeed inalienable, but also transferable in commission and license to a publisher. The bond the author has on his work confers him a moral right that is indeed a personal right. It is also a right to exploit economically his work in all possible ways, a right of economic use, which is a patrimonial right. Kant and Fichte argued that moral right and the right of economic use are strictly connected, and that the offense to one implies inevitably offense to the other. In eighteenth-century Germany, the free use came into discussion among the presuppositions of a democratic renewal of state and society. In his Supplement to the Consideration of Publishing and Its Rights, Reimarus asked writers "instead of writing for the aristocracy, to write for the tiers état of the reader's world." (Reimarus, 1791b, p.595). He saluted with enthusiasm the claim of disenfranchising from the monopoly of English publishers expressed in the American Act for the Encouragement of Learning of May 31, 1790. Kant, however, was firm in embracing intellectual property. Referring himself to Roman Law, he asked for its legislative formulation not only as patrimonial right, but also as a personal right. In Of the Illegitimity of Pirate Publishing, he considered the moral faculties related to intellectual property as an "inalienable right (ius personalissimum) always himself to speak through anyone else, the right, that is, that no one may deliver the same speech to the public other than in his (the author's) name" (Kant, 1902 , t.8, p.85). Fichte went farther in the Demonstration of the Illegitimity of Pirate Publishing. He saw intellectual property as a part of his metaphysical construction of intellectual activity, which was based on the principle that thoughts "are not transmitted hand to hand, they are not paid with shining cash, neither are they transmitted to us if we take home the book 
that contains them and put it into our library. In order to make those thoughts our own an action is still missing: we must read the book, meditate - provided it is not completely trivial - on its content, consider it under different aspects and eventually accept it within our connections of ideas" (Fichte, 1964, t.I/1, p.411).

At the center of the discussion was the practice of reprinting books in a pirate edition after having them reset word after words after an exemplar of the original edition. Given Germany's division in a myriad of small states, the imperial privilege was ineffective against pirate publishing. Kant and Fichte spoke for the acceptance of the right to defend the work of an author by the usurpations of others so that he may receive a patrimonial advantage from those who utilize the work acquiring new knowledge and/or an aesthetic experience. In particular, Fichte declared the absolute primacy of the moral faculties within the corpus mysticum. He divided the latter into a formal and a material part. "This intellectual element must be divided anew into what is material, the content of the book, the thoughts it presents; and the form of these thoughts, the manner in which, the connection in which, the formulations and the words by means of which the book presents them" (Fichte, 1964, t.I/1, p.411). Fichte's underlining the author's exclusive right to the intellectual content of his book - "the appropriation of which through another is physically impossible" (ibid.) - brought him to the extreme of prohibiting any form of copy that is not meant for personal use.

In Publishing Considered anew, Reimarus considered on the contrary copyright in its patrimonial aspects as a limitation to free trade: "What would not happen were a universal protection against pirate publishing guaranteed? Monopoly and safer sales certainly do not procure convenient price; on the contrary, they are at the origin of great abuses. The only condition for convenient price is free-trade, and one cannot help noticing that upon the appearance of a private edition, publishers are forced to substantially lower the price of a book" (Reimarus, 1791a, pp.402-3). Reimarus admitted of being unable to argue in terms of justice. Justice was of no bearing, he said, for whom, like himself, considered undemonstrated the author's permanent property of his work (herein supported by the legislative vacuum of those years). What mattered, he said, was equity. In sum, Reimarus anticipated today's stance on free use by referring to the principle that public interest on knowledge ought to prevail on the author's interest and to balance the copyright. Moreover, Reimarus extended his argument beyond the realm of literary production to embrace, among others, the today vital issue of pharmaceutical production on patented receipts. "Let us suppose that at some place a detailed description for the preparation of a good medicine or of any other useful thing be published, why may not somebody who lives in places that are far away from that one copy it to 
use it for his own profit and but must instead ask the original publisher for the issue of each exemplar?" (Reimarus, 1791b, t.2, pp.584). To sum up, Reimarus's stance does not seem respondent to rule of law. For in all dubious case the general rule ought to prevail, fighting intellectual property with anti-monopolistic arguments in favor of free trade brings with itself consequences that are not tranquilizing also for the ones that are expected to apply the law.

By resetting literary texts, one could obviously expurgate some errors. More frequently, however, some were added, given the exclusively commercial objectives of the reprints. The valid principle was, thus, that reprints were less precise than original editions, but they were much cheaper for the simple reason that the pirate publisher had a merely moral obligation against the author and the original publisher. In fact, he was not held to pay any honorarium to the author upon handling over the manuscript, nor to paying him royalties, nor to pay anything to the original publisher. The only expense in charge of the pirate publisher was buying the exemplar of the original edition out of which he was to make, as we say today, a free use.

\section{II}

Kant was not inclined to buying books. Partly out of Prussian thriftiness, which in the years preceding his celebrity had him make of necessity a virtue given the high price of books and the scantiness of his salary. And partly because in the sixties and seventies he lived, literally, above the bookstore of the bookseller and publisher Johann Jakob Kanter of Königsberg, who did not mind at all if Kant looked into all the books he wanted as long as they lay there in unbound sheets, waiting for buyers. A renown scholar that at the turn of his eightieth birthday finds himself the owner of a five-hundred volumes strong library (including paperbacks), cannot be said a bibliophile. There is more to that: from a philosophical point of view, Kant was a bibliophobe. Without doubt, Kant agreed with Plato that books are an ossifying vehicle of thought. The Reflexions on Logic contain a lapidary judgment of the nineties (the first part of which is a transcription without accents of the famous fragment $465 \mathrm{PF}$ by Callimachus): "Méga biblion: méga kakón. Big ossuary: library" (Kant, 1902, t.16, p.861). In truth, Kant was doing nothing else than following David Hume's (1711-1776) incendiary proposal in the last lines of the Inquiry concerning Human Understanding (section 12) that library owners should not hesitate to commit to the flames all books in which neither "abstract reasoning concerning quantity or number" nor "experimental reasoning concerning matters of fact or existence" were to be found. Instead of wishing a larger dissemination of books, 
as Reimarus in sum honestly did, Kant did not hesitate asking, in the Notes on the Observations on the Feeling of the Beautiful and the Sublime, for their reduction: "A damage, certainly not a minor one, among those provoked by the universal deluge of books that every year floods our continent is that people neglect the books that are really useful and that from time to time actually surface within the vast ocean of bookish erudition and that are condemned to share a destiny of rapid decay together with the rest of the chaff. There is a tendency to read a lot in order to say one has read. There is the habit not to delve long into a book" (Kant, 1902, t.20, p.42).

Kant interprets philosophically books as actual discourse. Truth is, though, that the argument Kant gave in Of the Illegitimacy of Pirate Publishing on the basis of the distinction between opus and opera refers back to Aristotle's doctrine of intellectual virtues, whereby the opus is the result of technê, the opera of phrônêsis: "The copy that the publisher has had printed is a work of the author (opus) and belongs entirely to the publisher, once he has negotiated for the manuscript or a printed copy, so that he can do whatever he wants with it that can be done in his own name; for that is requisite to a full right to a thing, that is, to a property. But such use as he can make of it only in the name of another (namely of the author) is an affair (opera) that this other carries on through the owner of the copy, and for this a separate contract is required, besides the one in regard to property" (Kant, 1902, t.8, p.84). The Aristotelian distinction shared by both Kant and Fichte (although none of them mastered Greek) between the tangible result of art as production (in Greek, poiein) of products that are decaying and contingent (in Latin, opus; plural, opera) and the activity (in Greek, prattein) of writing itself (in Latin, opera; plural, operae - these are no mere subtleties, they are fundamental for philosophical discourse, although one must admit that here Latin is, at least phonetically, almost ambiguous), which is particular and contingent too, but independent of any corporeity. They share also the distinction between product, activity, and thought (in Greek, noein), which takes the shapes of science, wisdom, and intellect, all dealing with universal and necessary objects. All this comes literally from the table of the five intellectual virtues in book Zeta of the Nicomachean Ethics (1139b-1141a). Going back to Aristotle, Kant affirmed then that the opus mechanicum is a thing (Sache) and therefore poioumenon, opus. This explains why works of art can be successfully imitated on the basis of a unique original exemplar. The corpus mysticum, is instead an action (Handlung) and therefore praxis, actio, opera, operatio, and can never be imitated because it is an action that the author acted only once and in his name. Consequently, if it is true that opera can exist as things for itself, the operae can exist only within one person. 


\section{III}

From the end of the eighteenth century, the issue of piracy comes back at the beginning of the twenty-first. In his ample introduction of ten years ago, Benoist considered in detail modern implications of Kant's Qu-estqu'un livre? (Benoist, 1995). He limited himself, however, to reproductions by means of print; and he spoke thus of photocopies, with a slight premonition of the new media offered by digital publishing. Kant and Fichte would be today supporters of the copyright and Reimarus of the copyleft. Meaning the nullity of copyright as regards economic use, the term copyleft has recently come into play to indicate the domain of the open sources, namely originally the software programs that their creators leave on the internet up for grabs for everybody who may wish them. Open sources have been disseminated in concurrence with the development of Linux-based operative systems. Not only can they be used freely, they can be integrated and enriched by everybody who may be willing and capable. Having said this, the author's will to share his work free of charge (on the internet are posted also a number of novels, poems, and music), does not imply his renunciation of authorial rights, which also within the copyleft approach are protected by means of the General Public License. The latter makes it possible for a copylefted product to be copied and modified as much as one may wish only if absence of copyright has been established, so that nobody in the future can attribute to himself the paternity of what he has copied and claim copyright.

The main arguments in favor of copyright have been formulated in 1995 in the Report of the Working Group on Intellectual Property Rights: Information Infrastructure Task Worce (1995). The information infrastructure (telephones, televisions, radios, computers and fax machines are used every day to receive, store, process, perform, display and transmit data, text, voice, sound and images in homes and businesses throughout the country) is having an enormous impact on the creation, reproduction and diffusion of copyrighted works. The information infrastructure has a tremendous potential to improve and enhance our lives, to access a greater amount and variety of information and entertainment resources around the world, to support our education systems, to increase democratic participation in government. On the other side, this brings about a severe disadvantage for authors. Authors are wary of entering this market because doing so exposes their works to a higher risk of piracy and other unauthorized uses than any of the traditional, current modes of dissemination. Therefore, authors may withhold their works from this environment. Further, even if authors choose not to expose their works to this more risky environment, the risk is not eliminated. Just one unauthorized uploading of a work onto a bulletin 
board, for instance - unlike, perhaps, most single reproductions and distributions in the analog or print environment - could have devastating effects on the market for the work.

The arguments in favor of copyleft have been formulated by Lawrence Lessig (2002). First, the copyleft license is the complement of the General Public License. It makes it possible for everybody to copy and distribute true copies of the license, i.e., provided no changes have been inserted. The object of such a license is to render a book or a textbook free in the sense of permitting everybody to copy and redistribute them with no changes, be it for profit or non-profit. Second, it makes it possible for authors and publishers to obtain public recognition of their work, be compensation tied or not tied to the recognition. Third, it preserves authors and publishers from liability arising from changes that have been inserted by others.

A compromise has been proposed by a working group of the Board on Science, Technology, and Economic Policy of the National Academy of Sciences that debated the issue of how intellectual properties rights can be extended. The results came out in a brochure with the title The Digital Dilemma (2000). Intellectual property will surely survive the digital age. It has become clear that the social effects of the information infrastructure generate a variety of interests, motivations, and values. Besides, the issue is not only of an economic or philosophical nature, it is technological. It is clear, however, that major adaptations will have to take place to ensure sufficient protection for content creators and rights holders, thereby helping to ensure that an extensive and diverse supply of intellectual property is available to the public. Finally, it is admitted that on global level, legislation is highly problematic. The committee has been cautious about major legislative initiatives because it is early in the evolution of digital intellectual property and much remains unknown - both because of the yet-to-come evolution in the information industries, user communities, and technologies and because of the need for research and data collection to improve knowledge and understanding of the issues. Under such circumstances, major changes in legal regimes and public policy, this is the conclusion, are ill-advised.

POZZO, R. Immanuel Kant sobre propriedade intelectual. Trans/Form/Ação, (São Paulo), v.29(2), 2006, p.11-18.

- RESUMO: Este texto inicialmente discute a noção de propriedade intelectual na filosofia de Kant e no século XVIII. Em seguida, recoloca o problema na atualidade em função das novas tecnologias de reprodução da informação.

- PALAVRAS-CHAVE: Kant; propriedade intelectual; pirataria; copyright; copyleft. 


\section{Bibliography}

BENOIST, J. Introduction. In: KANT, I. Qu'est-ce qu'un livre?. Paris: Puf, 1995.

FICHTE, J.G. Gesamtausgabe (GA). Band I-. Bayerischen Akademie der Wissenschaften. Stuttgart-Bad Cannstatt: Friedrich Frommann, 1964-

KANT, I. Gesammelte Schriften (KGS). Band I-, Königlich Preussichen Akademie der Wissenschaften. Berlim: Walter de Grunter \& Co, 1902-.

LESSIG, L. Free culture: The Nature and Future of Creativity. New York: Hardcore, 2002. Texto completo disponível em http://www.authorama.com/free-culture1.html <acesso em dezembro/2006>.

REIMARUS, J.A.H. Publishing Considered anew [Der Bücherverlag in Betrachtung der Schriftsteller, der Buchhändler und des Publikums abermals erwogen]. In: Deutsches Magazin, 1791a, t.I, pp.383-414. Texto completo disponível em http://www.ub.uni-bielefeld.de/diglib/aufkl/deutschmaga/deutschmaga.htm <acesso em dezembro/2006>.

Supplement to the Consideration of Publishing and Its Rights [Nachtrag zu der Erwärung des Bücherverlags und dessen Rechte]. In: Deutsches Magazin, 1791b, t.II, pp.564-596. Texto completo disponível em http://www.ub.unibielefeld.de/diglib/aufkl/deutschmaga/deutschmaga.htm <acesso em dezembro/2006>

Report of the Working Group on Intellectual Property Rights: Information Infrastructure Task Worce. Texto completo disponível em http://www.ladas.com/NII $<$ acesso em dezembro/2006>

The Digital Dilemma: intellectual property in the information age. New York, Paperback, 2000. Texto completo disponível em http://books.nap.edu/catalog/ 9601.html <acesso em dezembro/2006> 